\title{
Extraction of koumine from Gelsemium Elegans Benth. and its therapeutic effect on collagen-induced arthritis in mice
}

\author{
Zhengfei $\mathrm{LI}^{1}$, Jieying ZHANG ${ }^{1 *}$ (D), Ren $\mathrm{ZHANG}^{1}$, Yao KUANG ${ }^{1}$
}

\begin{abstract}
This study aimed to investigate the therapeutic effect of koumine on collagen-induced arthritis (CIA) in mice. Koumine was extracted from Gelsemium Elegans Benth. The CIA model was established in Balb/c mice. Forty successfully modeled mice were randomly divided into model group and 2,4 and $8 \mathrm{mg} / \mathrm{kg}$ koumine groups, 10 mice in each group. Another 10 normal mice were selected as control group. The 2,4 and $8 \mathrm{mg} / \mathrm{kg}$ koumine groups were treated with $2,4 \mathrm{and} 8 \mathrm{mg} / \mathrm{kg} \mathrm{koumine}$, respectively, for three successive weeks. At the end of treatment, compared with model group, in 4 and $8 \mathrm{mg} / \mathrm{kg}$ koumine groups the arthritis index was significantly decreased $(\mathrm{P}<0.05)$, the peripheral blood interleukin-17 level and T helper $17(\mathrm{Th} 17)$ cell percentage were significantly decreased $(\mathrm{P}<0.05)$, the peripheral blood interleukin-10 level and regulatory $\mathrm{T}(\mathrm{Treg})$ cell percentage were significantly increased $(\mathrm{P}<0.05)$, the spleen tissue ROR $\gamma$ t protein expression level was significantly decreased $(\mathrm{P}<0.05)$, and the spleen tissue Foxp3 protein expression level was significantly increased $(\mathrm{P}<0.05)$. In conclusion, koumine has therapeutic effect on CIA in mice. The mechanism may be related to its regulating the ROR $\gamma \mathrm{t} / \mathrm{Foxp} 3$ expressions, thus correcting the Th17/Treg immune imbalance.
\end{abstract}

Keywords: koumine; collagen-induced arthritis; mice; Th17, Treg.

Practical Application: This study has provided a reference for obtaining koumine from Gelsemium Elegans Benth. and using koumine to treat rheumatoid arthritis.

\section{Introduction}

Rheumatoid arthritis is a kind of multiple-systemic and inflammatory autoimmune disease involving the joints. The main clinical manifestations of rheumatoid arthritis are the symmetric joint swelling and pain, erosive synovitis, and even progressive joint injury and deformity (Dayer, 2003). Rheumatoid arthritis can lead to the patients' pain, disability and loss of labor force. In addition, the rheumatoid arthritis patients are prone to suffer from a variety of chronic diseases, which seriously affects the functional status and life quality, and significantly reduces the life expectancy (Scott et al., 2000). At present, the drug therapy is the main means to treat rheumatoid arthritis. The drugs include non-steroidal anti-inflammatory drugs (NSAIDs), disease-modifying anti-rheumatic drugs (DMARDs), glucocorticoids and biological agents. NSAIDs, DMARDs and glucocorticoids are mainly used to relieve the joint pain and swelling symptoms of rheumatoid arthritis patients, and reduce the joint damage, but they cannot change the progress of disease (Gøtzsche, 1989; Ten Wolde et al., 1996; Cutolo, 2016). The biological agents mainly exert the therapeutic effect through intervening to the immune mechanism related to rheumatoid arthritis pathogenesis. Their effect is better than that of traditional drugs, but these drugs are expensive, and have the risk of causing tuberculosis, serious infection and tumor (Timlin \& Bingham, 2014; Singh et al., 2015; Yun et al., 2016). Therefore, the new high-efficiency and low-toxicity drugs still need to be developed for treatment of rheumatoid arthritis.
There were many kinds of plant and their components have the anti-inflammatory and immunomodulatory activities (Costa et al., 2020; Prasanth et al., 2020). Koumine (molecular formula: $\mathrm{C}_{20} \mathrm{H}_{22} \mathrm{~N}_{2} \mathrm{O}$; molecular weight: 306.40148 ) is an alkaloid monomer isolated from the medicinal plant Gelsemium Elegans Benth.. Previous studies have shown that koumine has the anti-inflammatory, immunity-regulating and analgesic effects (Rujjanawate et al., 2003; Xu et al., 2012), but whether it can be used for treatment of rheumatoid arthritis is unclear. It is found that the imbalance of Thelper 17 (Th17) and regulatory $\mathrm{T}$ (Treg) cells plays an important role in the development of rheumatoid arthritis (Boissier et al., 2008; Wang et al., 2012). This study established the collagen-induced arthritis (CIA) model of mice, and investigated the therapeutic effect of koumine on CIA and its relation with Th17/Treg immune balance.

\section{Materials and methods}

\subsection{Extraction of koumine from Gelsemium Elegans Benth.}

One kilogram dry powder (30-40 mesh) of Gelsemium Elegans Benth. root bark was prepared, and was placed in $10 \mathrm{~L}$ extraction flask, followed by adding $5000 \mathrm{~mL}$ chloroform. The reflux extraction was performed for $2.5 \mathrm{~h}$. After filtering, the filtrate was concentrated by vacuum at $45^{\circ} \mathrm{C}$. The reddish brown concentrated solution was obtained. The filter residue extracted with $5000 \mathrm{~mL}$ chloroform again. After filtering and 
concentration by vacuum at $45^{\circ} \mathrm{C}$, the second reddish brown concentrated solution was obtained. The two concentrated solutions were combined, followed by extracting with $1500 \mathrm{~mL}$ $0.5 \% \mathrm{HCl}$ solution for three times. The three times of extracted $\mathrm{HCl}$ solution were combined, and the $\mathrm{pH}$ was adjusted to $11 \mathrm{using}$ $5 \mathrm{~mol} / \mathrm{L} \mathrm{NaOH}$ solution, followed by extracting with chloroform for three times. The three times of extracted chloroform were combined. After concentrating by vacuum at $45^{\circ} \mathrm{C}$, the crude extract was obtained. The crude extract was loaded on the silica gel column, followed by gradient elution with different proportions of chloroform-methanol. The target elution solution was collected, and was concentrated by vacuum at $45^{\circ} \mathrm{C}$. The solid powder was recrystallized with acetone, and the final koumine product was obtained. The HPLC purity was $98.13 \%$.

\subsection{Establishment of CIA model}

Bovine type II collagen was dissolved in $0.01 \mathrm{~mol} / \mathrm{L}$ acetic acid solution to prepare the solution with final type II collagen concentration of $2 \mathrm{~g} / \mathrm{L}$. The solution was mixed with complete Freund adjuvant in the volume ratio of $1: 1$, followed completely emulsifying. The mixed emulsion was obtained. Male Balb/c mice were fed adaptively for one week. On the first day of experiment (day 1), $100 \mu \mathrm{L}$ mixed emulsion was intracutaneously injected into the caudal root of mice for the primary immunization. On day 21, $100 \mu \mathrm{L}$ mixed emulsion was injected into the caudal root by the same method for the strengthened immunization. The normal mice as control were injected with equal amount of normal saline. The success of modeling was determined by arthritis scoring

\subsection{Animal grouping and treatment}

Forty successfully modeled mice were randomly divided into model group and 2, 4 and $8 \mathrm{mg} / \mathrm{kg}$ koumine groups, 10 mice in each group. Another 10 normal mice were selected as control group. From day 22, the 2, 4 and $8 \mathrm{mg} / \mathrm{kg}$ koumine groups were given 2, 4 and $8 \mathrm{mg} / \mathrm{kg}$ koumine (HPLC purity $\geq 98 \%$; Huzhou Zhanshu Biotechnology Co., Ltd., Huzhou, China) by gavage, respectively. The control and model groups were given the same amount of normal saline by gavage. The treatment was performed once a day, for three successive weeks (from day 22 to day 42).

\subsection{Arthritis scoring}

On day 22, 27, 32, 37 and 42, the degree of arthritis was evaluated using 5-grade arthritis scoring method as follows: 0 point: no redness or swelling; 1 point: slight redness or swelling of local toes or ankle joints; 2 points: slight swelling of joint and toe; 3 points: swelling of and ankle joints; 4 points: redness and swelling of all toes and ankle joints or joint deformity. The cumulative scores of four limbs presented the arthritis index of each mouse. The arthritis index value $\geq 4$ points indicated the successful molding of CIA.

\subsection{Determination of peripheral blood inflammatory factors and Th17 and Treg cells}

At the end of treatment, the blood was collected from the mice by the picking the eyeball. Partial blood was centrifuged at
$3000 \mathrm{r} / \mathrm{min}$ for $10 \mathrm{~min}$, and the serum was obtained. The levels of interleukin-17 (IL-17) and interleukin-10 (IL-10) were determined using enzyme linked immunosorbent assay. Partial blood was loaded on the flow cytometry, and the percentages of Th17 and Treg cells were determined. The procedures were in accordance to the instructions of kits and equipments.

\subsection{Determination of Foxp3 and RORyt protein expressions in spleen tissues}

Western blot was used to determine the expression of Foxp 3 and ROR $\gamma \mathrm{t}$ proteins in spleen tissues. The mice were killed. The spleen tissues were taken, and were added with RIPA tissue lysate. After $5 \mathrm{~min}$ of ice bathing, the mixture was centrifuged at $13000 \mathrm{r} / \mathrm{min}$ and $4{ }^{\circ} \mathrm{C}$ for $10 \mathrm{~min}$. The supernatant was obtained and the protein content was determined by bicinchoninic acid method. A $50 \mu \mathrm{g}$ protein sample was taken, and was loaded on sodium dodecyl sulfatepolyacrylamide gel electrophoresis. The separated proteins were transferred to polyvinylidene fluoride membranes, followed by blocking with 5\% skim milk powder at room temperature for $1 \mathrm{~h}$. The membranes were incubated with the primary antibody of Foxp3, ROR $\gamma$ t and $\beta$-actin at $4{ }^{\circ} \mathrm{C}$ overnight, respectively. On the next day, the membranes were incubated with the horseradish peroxidase labeled secondary antibody at room temperature for $1 \mathrm{~h}$. Finally, the membranes were developed with electrochemiluminescence reagent, followed by photographing and gray scanning. The gray value of the strip on membranes was analyzed with ImageJ software. The relative expression of protein was presented by the ratio of its strip gray value to $\beta$-actin strip gray value.

\subsection{Statistical analysis}

All data were shown by mean \pm standard deviation, and were analyzed using SPSS 17.0 software. The statistical comparison was carried out with five groups using one-way analysis of variance (ANOVA), and then the differences among means were analyzed using Dunnett's test. Differences were considered significant at $\mathrm{P}<0.05$.

\section{Results}

\subsection{General condition of mice in five groups}

In five groups, no mouse died during the treatment period. The mice in control group had normal diet and activities and glossy fur. The mice in model group presented decreased appetite, reduced weight, dull and dry fur, mild depilation, joint redness and deformity and lameness. Compared with control group, the mice in three koumine groups still the rheumatoid arthritis performances, but they were slighter than model group.

\subsection{Comparison of arthritis index among five groups}

At each time point, the arthritis index in model and 2, 4 and $8 \mathrm{mg} / \mathrm{kg}$ koumine groups was significantly higher than that in control group, respectively $(\mathrm{P}<0.05)$. On day 22,27 and 32 , the arthritis index had no significant difference among model and 2, 4 and $8 \mathrm{mg} / \mathrm{kg}$ koumine groups, respectively $(\mathrm{P}>0.05)$. On day 37 and 42, the arthritis index had no 
significant difference between model and $2 \mathrm{mg} / \mathrm{kg}$ koumine groups, respectively $(\mathrm{P}>0.05)$, but that in 4 and $8 \mathrm{mg} / \mathrm{kg}$ koumine groups was significantly lower than that in model group, respectively $(\mathrm{P}<0.05)$ (Figure 1$)$.

\subsection{Comparison of peripheral blood IL-17 and IL-10 levels among five groups}

At the end of treatment, the peripheral blood IL-17 level in model and 2, 4 and $8 \mathrm{mg} / \mathrm{kg}$ koumine groups was significantly higher than that in control group, respectively $(\mathrm{P}<0.05)$, and the IL-10 level in model and 2, 4 and $8 \mathrm{mg} /$ $\mathrm{kg}$ koumine groups was significantly lower than that in control group, respectively $(\mathrm{P}<0.05)$. Compared with model group, in 4 and $8 \mathrm{mg} / \mathrm{kg}$ koumine groups the IL-17 level was significantly decreased, respectively $(\mathrm{P}<0.05)$, and the IL-10 level was significantly increased, respectively $(\mathrm{P}<0.05)$ (Table 1).

\subsection{Comparison of peripheral blood Th17 and Treg cell percentages among five groups}

Table 2 showed that, at the end of treatment, compared with control group, in model and 2, 4 and $8 \mathrm{mg} / \mathrm{kg}$ koumine groups the peripheral Th17 cell percentage was significantly increased, respectively $(\mathrm{P}<0.05)$, and the Treg cell percentage was significantly decreased, respectively $(\mathrm{P}<0.05)$. Compared with model group, in 2, 4 and $8 \mathrm{mg} / \mathrm{kg}$ koumine groups the Th17 cell percentage was significantly decreased, respectively $(\mathrm{P}<0.05)$, and the Treg cell percentage was significantly increased, respectively $(\mathrm{P}<0.05)$.

\subsection{Comparison of spleen tissue Foxp3 and ROR $y$ t protein expressions among five groups}

At the end of treatment, the spleen tissue Foxp3 protein expression level in model and 2, 4 and $8 \mathrm{mg} / \mathrm{kg}$ koumine groups was significantly higher than that in control group, respectively $(\mathrm{P}<0.05)$, and the ROR $\gamma t$ protein expression level in model and 2, 4 and $8 \mathrm{mg} / \mathrm{kg}$ koumine groups was significantly lower than that in control group, respectively $(\mathrm{P}<0.05)$. Compared with model group, in 4 and $8 \mathrm{mg} / \mathrm{kg}$ koumine groups the Foxp3 protein expression level was significantly decreased, respectively $(\mathrm{P}<0.05)$, and the ROR $\gamma t$ protein expression level was significantly increased, respectively $(\mathrm{P}<0.05)$ (Table 3 ).

Table 1. Comparison of peripheral blood IL-17 and IL-10 levels among five groups.

\begin{tabular}{cccc}
\hline Group & $\mathrm{n}$ & IL-17 (ng/L) & IL-10 (ng/L) \\
\hline Control & 10 & $4.21 \pm 0.63$ & $74.63 \pm 15.04$ \\
Model & 10 & $7.82 \pm 1.12^{\mathrm{a}}$ & $42.38 \pm 7.39^{\mathrm{a}}$ \\
$2 \mathrm{mg} / \mathrm{kg}$ koumine & 10 & $7.12 \pm 1.03^{\mathrm{a}}$ & $46.90 \pm 9.77^{\mathrm{a}}$ \\
$4 \mathrm{mg} / \mathrm{kg}$ koumine & 10 & $6.40 \pm 0.94^{\mathrm{ab}}$ & $51.17 \pm 7.28^{\mathrm{ab}}$ \\
$8 \mathrm{mg} / \mathrm{kg}$ koumine & 10 & $5.29 \pm 0.73^{\mathrm{abcd}}$ & $58.04 \pm 10.51^{\mathrm{abcd}}$ \\
\hline${ }^{\mathrm{a}} \mathrm{P}<0.05$ compared with control group; ${ }^{\mathrm{b}} \mathrm{P}<0.05$ compared with model group; ${ }^{\mathrm{P}}<0.05$ \\
compared with $2 \mathrm{mg} / \mathrm{kg}$ koumine group; ${ }^{\mathrm{P}}<0.05$ compared with $4 \mathrm{mg} / \mathrm{kg}$ koumine \\
group. IL-17, interleukin-17; IL-10, interleukin-10.
\end{tabular}

Table 2. Comparison of peripheral blood Th17 and Treg cell percentages among five groups.

\begin{tabular}{cccc}
\hline Group & $\mathrm{n}$ & Th17 cells (\%) & Treg cells (\%) \\
\hline Control & 10 & $0.47 \pm 0.08$ & $2.13 \pm 0.15$ \\
Model & 10 & $1.12 \pm 0.24^{\mathrm{a}}$ & $1.18 \pm 0.15^{\mathrm{a}}$ \\
$2 \mathrm{mg} / \mathrm{kg}$ koumine & 10 & $0.95 \pm 0.16^{\mathrm{ab}}$ & $1.36 \pm 0.16^{\mathrm{ab}}$ \\
$4 \mathrm{mg} / \mathrm{kg}$ koumine & 10 & $0.70 \pm 0.18^{\mathrm{abc}}$ & $1.52 \pm 0.20^{\mathrm{ab}}$ \\
$8 \mathrm{mg} / \mathrm{kg}$ koumine & 10 & $0.62 \pm 0.11^{\mathrm{abc}}$ & $1.8 \pm 0.26^{\mathrm{abcd}}$ \\
\hline${ }^{\mathrm{a} P}<0.05$ compared with control group; ${ }^{\mathrm{b}} \mathrm{P}<0.05$ compared with model group; ${ }^{\mathrm{c}} \mathrm{P}<0.05$ \\
compared with $2 \mathrm{mg} / \mathrm{kg}$ koumine group; ${ }^{\mathrm{d}} \mathrm{P}<0.05$ compared with $4 \mathrm{mg} / \mathrm{kg}$ koumine group.
\end{tabular}

Table 3. Comparison of spleen tissue Foxp3 and ROR $\gamma$ t protein expressions among five groups.

\begin{tabular}{cccc}
\hline Group & $\mathrm{n}$ & ROR $\gamma \mathrm{t} / \beta$-actin & Foxp3/ $\beta$-actin \\
\hline Control & 10 & $0.31 \pm 0.03$ & $0.63 \pm 0.08$ \\
Model & 10 & $0.57 \pm 0.04^{\mathrm{a}}$ & $0.29 \pm 0.03^{\mathrm{a}}$ \\
$2 \mathrm{mg} / \mathrm{kg}$ koumine & 10 & $0.55 \pm 0.02^{\mathrm{a}}$ & $0.33 \pm 0.04^{\mathrm{a}}$ \\
$4 \mathrm{mg} / \mathrm{kg}$ koumine & 10 & $0.47 \pm 0.04^{\mathrm{abc}}$ & $0.41 \pm 0.03^{\mathrm{abc}}$ \\
$8 \mathrm{mg} / \mathrm{kg}$ koumine & 10 & $0.45 \pm 0.06^{\mathrm{abc}}$ & $0.50 \pm 0.07^{\mathrm{abcd}}$ \\
\hline${ }^{\text {aP }}<0.05$ compared with control group; ${ }^{\mathrm{b}} \mathrm{P}<0.05$ compared with model group; ${ }^{\mathrm{c}} \mathrm{P}<0.05$ \\
compared with $2 \mathrm{mg} / \mathrm{kg}$ koumine group; ${ }^{\mathrm{d}} \mathrm{P}<0.05$ compared with $4 \mathrm{mg} / \mathrm{kg}$ koumine group.
\end{tabular}

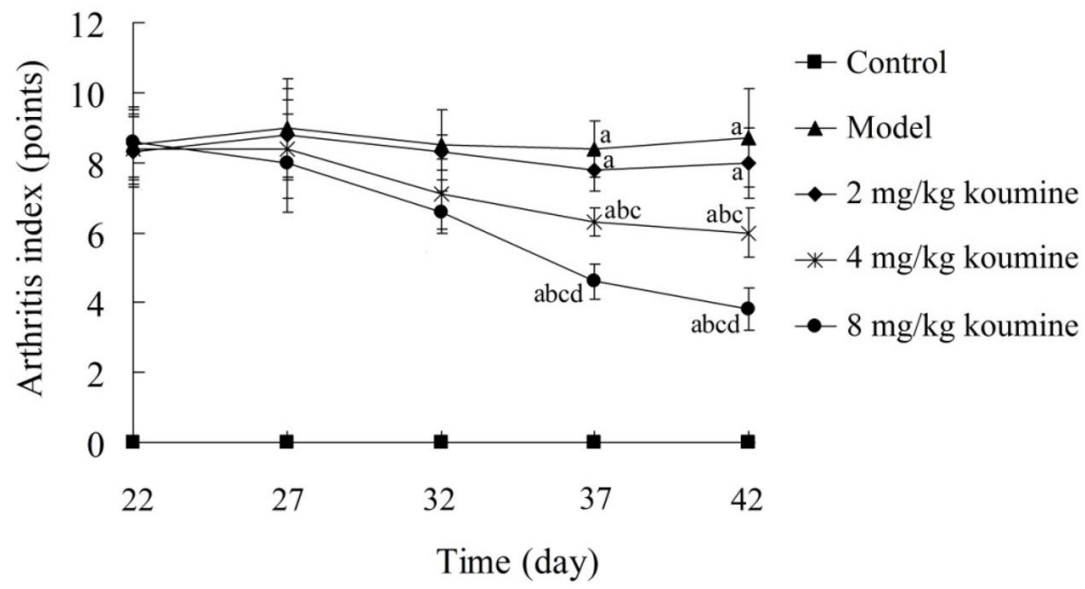

Figure 1. Comparison of arthritis index of mice among five groups. ${ }^{\text {P }}<0.05$ compared with control group; ${ }^{\mathrm{b}} \mathrm{P}<0.05$ compared with model group; ${ }^{\mathrm{P}}<0.05$ compared with $2 \mathrm{mg} / \mathrm{kg}$ koumine group; ${ }^{\mathrm{d}} \mathrm{P}<0.05$ compared with $4 \mathrm{mg} / \mathrm{kg}$ koumine group. 


\section{Discussion}

Rheumatoid arthritis is a common chronic systemic autoimmune disease. At present, rheumatoid arthritis is mainly treated by NSAIDs, DMARDs, glucocorticoids and biological agents. These drugs have some curative effects, but they have some limitations more or less. In this study koumine with purity of $98.13 \%$ was obtained from Gelsemium Elegans Benth., and the therapeutic effect of koumine on CIA in mice was investigated. Results showed that, after treated with koumine, the rheumatoid arthritis symptoms of CIA were obviously relieved, and arthritis index was significantly decreased. This indicates that koumine has the therapeutic effect on CIA.

$\mathrm{CD}^{+} \mathrm{T}$ cells are the important adaptive immune cells, and their abnormal differentiation in rheumatoid arthritis has been paid more and more attention (Martens et al., 1997). Th17 and Treg cells are two subtypes of $\mathrm{CD} 4^{+} \mathrm{T}$ cells. Th17 cells mainly secrete IL-17, which is a strong inflammatory factor. IL-17 has biological activity at a very low concentration, and has a high affinity with the receptors. IL-17 can promote the infiltration of immune cells into the synovium of the joint, and stimulate fibroblasts to produce more pro-inflammatory factors (Chabaud et al., 2001). It has synergistic effect with IL-1, IL-6, TNF- $\alpha$ and other pro-inflammatory factors, further aggravating the inflammatory response (Amara et al., 2015). Treg cells can secrete IL-10, which inhibits the release of TNF- $\alpha$, IFN- $\gamma$ and other pro-inflammatory factors (Tabares et al., 2014). They can also play a direct role in repairing the tissues, promoting the immune tolerance, and maintaining the immune homeostasis (Hu et al., 2019). In our study, at the end of treatment, compared with control group, in other groups the peripheral blood IL-17 level and Th17 cell percentage were significantly increased, and the IL-10 level and Treg cell percentage were significantly decreased. This suggests that, the Th17/Treg immune imbalance is involved in the CIA in mice. Compared with model group, in koumine groups the IL-17 level and Th17 cell percentage were significantly decreased, and the IL-10 level and Treg cell percentage were significantly increased. This suggests that, the koumine treatment can correct the Th17/Treg immune imbalance, thus alleviating the CIA in mice.

ROR $\gamma t$ is the key transcription factor of Th17 cells, which can specifically regulate the differentiation and function of Th17 cells (Dambacher et al., 2009). It is found that, in animals with ROR $\gamma t$ deficiency, the number of Th17 cells is decreased, and the probability of autoimmune diseases is reduced (Ivanov et al., 2006). Foxp3 is a marker molecule of Treg cells. It plays a key role in the differentiation, development, maturation and immunosuppression of Treg cells. It is also the most sensitive marker of Treg cells (Arruvito et al., 2010). Foxp3 is antagonistic to ROR $\gamma$ t. The balance of ROR $\gamma \mathrm{t} /$ Foxp3 can determine the differentiation direction of initial CD4 ${ }^{+} \mathrm{T}$ cells to Th17 or Treg cells after being stimulated by antigens, thus fundamentally affecting the occurrence and development of autoimmune diseases such as rheumatoid arthritis (Tada et al., 2016). Results of this study showed that, at the end of treatment, compared with control group, in other groups the spleen tissue ROR $\gamma t$ protein expression level was significantly increased, and the Foxp3 protein expression level was significantly decreased. This confirms that the balance of
ROR $\gamma \mathrm{t} /$ Foxp3 is broken in CIA mice. Compared with model group, in koumine groups the ROR $\gamma \mathrm{t}$ protein expression level was significantly decreased, and the Foxp3 protein expression level was significantly increased. This indicates that, the koumine treatment can regulate the ROR $\gamma \mathrm{t} /$ Foxp3 expressions, which may be related to its correcting the Th17/Treg immune imbalance in mice with CIA.

\section{Conclusion}

Koumine is obtained from Gelsemium Elegans Benth., and its purity is $98.13 \%$. Koumine has therapeutic effect on CIA in mice. The mechanism may be related to its regulating the ROR $\gamma \mathrm{t} /$ Foxp3 expressions, thus correcting the Th17/Treg immune imbalance. However, the other action mechanisms of koumine in treating CIA still need to be further explored.

\section{References}

Amara, S., Lopez, K., Banan, B., Brown, S. K., Whalen, M., Myles, E., Ivy, M. T., Johnson, T., Schey, K. L., \& Tiriveedhi, V. (2015). Synergistic effect of pro-inflammatory TNFa and IL-17 in periostin mediated collagen deposition: potential role in liver fibrosis. Molecular Immunology, 64(1), 26-35. http://dx.doi.org/10.1016/j. molimm.2014.10.021. PMid:25467797.

Arruvito, L., Sotelo, A. I., Billordo, A., \& Fainboim, L. (2010). A physiological role for inducible FOXP3(+) Treg cells: lessons from women with reproductive failure. Clinical Immunology, 136(3), 432441. http://dx.doi.org/10.1016/j.clim.2010.05.002. PMid:20542739.

Boissier, M. C., Assier, E., Falgarone, G., \& Bessis, N. (2008). Shifting the imbalance from Th1/Th2 to Th17/treg: the changing rheumatoid arthritis paradigm. Joint, Bone, Spine, 75(4), 373-375. http://dx.doi. org/10.1016/j.jbspin.2008.04.005. PMid:18571969.

Chabaud, M., Lubberts, E., Joosten, L., van Den Berg, W., \& Miossec, P. (2001). IL-17 derived from juxta-articular bone and synovium contributes to joint degradation in rheumatoid arthritis. Arthritis Research,3(3), 168-177. http://dx.doi.org/10.1186/ar294. PMid:11299057.

Costa, G. L. A., Buccini, D. F., Arruda, A. L. A., Favaro, S. P., \& Moreno, S. E. (2020). Phytochemical profile, anti-inflammatory, antimutagenic and antioxidant properties of Acrocomia aculeata (Jacq.) Lodd. pulp oil. Food Sci Tech., 40(4), 963-971. http://dx.doi.org/10.1590/fst.25319.

Cutolo, M. (2016). Glucocorticoids and chronotherapy in rheumatoid arthritis. RMD Open, 2(1), e000203. http://dx.doi.org/10.1136/ rmdopen-2015-000203. PMid:27042335.

Dambacher, J., Beigel, F., Zitzmann, K., De Toni, E. N., Göke, B., Diepolder, H. M., Auernhammer, C. J., \& Brand, S. (2009). The role of the novel Th17 cytokine IL-26 in intestinal inflammation. Gut, 58(9), 12071217. http://dx.doi.org/10.1136/gut.2007.130112. PMid:18483078.

Dayer, J. M. (2003). The pivotal role of interleukin-1 in the clinical manifestations of rheumatoid arthritis. Rheumatology, 42(90002, Suppl. 2), ii3-ii10. http://dx.doi.org/10.1093/rheumatology/keg326. PMid:12817089.

Gøtzsche, P. C. (1989). Review of dose-response studies of NSAIDs in rheumatoid arthritis. Danish Medical Bulletin, 36(4), 395-399. PMid:2680311.

Hu, Y., Zhou, H., Gao, B., Wang, G., \& Wang, Y. (2019). Role of regulatory $\mathrm{T}$ cells in CD47/donor-specific transfusion-induced immune tolerance in skin-heart transplantation mice. Transplant Infectious Disease, 21(1), e13012. http://dx.doi.org/10.1111/tid.13012. PMid:30320937.

Ivanov, I. I., McKenzie, B. S., Zhou, L., Tadokoro, C. E., Lepelley, A., Lafaille, J. J., Cua, D. J., \& Littman, D. R. (2006). The orphan 
nuclear receptor RORgammat directs the differentiation program of proinflammatory IL-17+ T helper cells. Cell, 126(6), 1121-1133. http://dx.doi.org/10.1016/j.cell.2006.07.035. PMid:16990136.

Martens, P. B., Goronzy, J. J., Schaid, D., \& Weyand, C. M. (1997). Expansion of unusual CD4+ T cells in severe rheumatoid arthritis. Arthritis and Rheumatism, 40(6), 1106-1114.http://dx.doi.org/10.1002/ art.1780400615. PMid:9182921.

Prasanth, M. I., Sivamaruthi, B. S., Sukprasansap, M., Chuchawankul, S., Tencomnao, T., \& Chaiyasut, C. (2020). Functional properties and Bioactivities of Cleistocalyx nervosum var. paniala berry plant: a review. Food Sci Tech., 40(Suppl. 2), 369-373. http://dx.doi. org/10.1590/fst.30719.

Rujjanawate, C., Kanjanapothi, D., \& Panthong, A. (2003). Pharmacological effect and toxicity of alkaloids from Gelsemium elegans Benth. Journal of Ethnopharmacology, 89(1), 91-95. http://dx.doi.org/10.1016/ S0378-8741(03)00267-8. PMid:14522437.

Scott, D. L., Pugner, K., Kaarela, K., Doyle, D. V., Woolf, A., Holmes, J., \& Hieke, K. (2000). The links between joint damage and disability in rheumatoid arthritis. Rheumatology, 39(2), 122-132. http://dx.doi. org/10.1093/rheumatology/39.2.122. PMid:10725061.

Singh, J. A., Cameron, C., Noorbaloochi, S., Cullis, T., Tucker, M., Christensen, R., Ghogomu, E. T., Coyle, D., Clifford, T., Tugwell, P., \& Wells, G. A. (2015). Risk of serious infection in biological treatment of patients with rheumatoid arthritis: a systematic review and meta-analysis. Lancet, 386(9990), 258-265. http://dx.doi.org/10.1016/S0140-6736(14)61704-9. PMid:25975452.

Tabares, P., Berr, S., Römer, P. S., Chuvpilo, S., Matskevich, A. A., Tyrsin, D., Fedotov, Y., Einsele, H., Tony, H. P., \& Hünig, T. (2014). Human regulatory $\mathrm{T}$ cells are selectively activated by low-dose application of the CD28 superagonist TGN1412/TAB08. European Journal of Immunology, 44(4), 1225-1236. http://dx.doi.org/10.1002/ eji.201343967. PMid:24374661.
Tada, Y., Ono, N., Suematsu, R., Tashiro, S., Sadanaga, Y., Tokuda, Y., Ono, Y., Nakao, Y., Maruyama, A., Ohta, A., \& Koarada, S. (2016). The balance between Foxp3 and Ror- $\gamma \mathrm{t}$ expression in peripheral blood is altered by tocilizumab and abatacept in patients with rheumatoid arthritis. BMC Musculoskeletal Disorders, 17(1), 290. http://dx.doi. org/10.1186/s12891-016-1137-1. PMid:27421886.

Ten Wolde, S., Dijkmans, B. A., Janssen, M., Hermans, J., \& Lamers, C. B. (1996). High-dose ranitidine for the prevention of recurrent peptic ulcer disease in rheumatoid arthritis patients taking NSAIDs. Alimentary Pharmacology \& Therapeutics, 10(3), 347-351. http://dx.doi.org/10.1111/j.0953-0673.1996.00347.x. PMid:8791962.

Timlin, H., \& Bingham, C. O. 3rd (2014). Efficacy and safety implications of molecular constructs of biological agents for rheumatoid arthritis. Expert Opinion on Biological Therapy, 14(7), 893-904. http://dx.doi. org/10.1517/14712598.2014.900536. PMid:24720727.

Wang, W., Shao, S., Jiao, Z., Guo, M., Xu, H., \& Wang, S. (2012). The Th17/Treg imbalance and cytokine environment in peripheral blood of patients with rheumatoid arthritis. Rheumatology International, 32(4), 887-893. http://dx.doi.org/10.1007/s00296-010-1710-0. PMid:21221592.

Xu, Y., Qiu, H. Q., Liu, H., Liu, M., Huang, Z. Y., Yang, J., Su, Y. P., \& Yu, C. X. (2012). Effects of koumine, an alkaloid of Gelsemium elegans Benth., on inflammatory and neuropathic pain models and possible mechanism with allopregnanolone. Pharmacology, Biochemistry, and Behavior, 101(3), 504-514. http://dx.doi.org/10.1016/j.pbb.2012.02.009. PMid:22366214.

Yun, H., Xie, F., Delzell, E., Levitan, E. B., Chen, L., Lewis, J. D., Saag, K. G., Beukelman, T., Winthrop, K. L., Baddley, J. W., \& Curtis, J. R. (2016). Comparative risk of hospitalized infection associated with biologic agents in rheumatoid arthritis patients enrolled in medicare. Arthritis \& Rheumatology, 68(1), 56-66. http://dx.doi. org/10.1002/art.39399. PMid:26315675. 